\title{
Clinical significance of antibodies to soluble extractable nuclear antigens (anti-ENA)
}

\author{
A. GAUDREAU*, B. AMOR $\dagger$, M. F. KAHN + , A. RYCKEWAERT**, \\ J. SANY $\dagger$, AND A. P. PELTIER++
}

From the Sero-Immunology Laboratories, Unité de Recherche INSERM no. 18 and Clinique Rhumatologique, Centre Viggo Petersen, Hôpital Lariboisière, 75010 Paris, France

SUMMARY Clinical and biological manifestations have been studied in 134 patients whose serum had antibodies to soluble extractable nuclear antigens (ENA). 85 of the patients had anti-RNP antibodies, 18 had anti-Sm antibodies, and 31 had antibodies to one or more soluble nuclear antigen. In all groups, the predominant clinical manifestations were polyarthritis, Raynaud's phenomenon, fever, and skin involvement. Renal disease was less common in those patients with anti-RNP antibodies than in the other patients. Most patients with definite renal disease (13 out of 15) also had circulating anti-DNA antibodies. The final diagnoses in these 134 patients were well defined connective tissue disease in 59; overlap syndromes in 34; a limited clinical syndrome made up of polyarthritis Raynaud's phenomenon - often with swollen fingers - and/or hypergammaglobulinaemia in 31, and various other clinical conditions in 10.

The presence of antibodies reacting with soluble extractable nuclear antigens (ENA) in the serum of patients with systemic lupus erythematosus (SLE) was established for the first time by Holman et al. (1959).

Subsequent studies led to the identification of two of these antigens (antigens Sm and RNP) (Tan and Kunkel, 1966; Mattioli and Reichlin, 1971) and more recently of 3 or 4 other antigens (PM1, SSA and SSB, and antigen $\mathrm{Ha}$; Alspaugh and Tan, 1973; Akizuki et al., 1977; Wolfe et al., 1977). One of us (Peltier et al., 1977b) has recently characterised a soluble nuclear antigen which seems to be a protein and whose properties are very similar to those of antigen $\mathrm{Ha}$ and antigen SSB.

Accepted for publication November 13, 1977

Correspondence to Dr A. P. Peltier, Unité de Recherche INSERM no. 18, Hôpital Lariboisière, 6, rue Guy Patin, 75010 Paris, France.

* Fellow of the Canadian Arthritis Society.

†Institut de Rhumatologie et Centre de Recherche sur les Maladies Ostéo-articulaires (Unité INSERM no. 5), Hôpital Conchin, Paris, France.

†Service de Rhumatologie, Hôpital Bichat, Paris, France.

**Clinique Rhumatologique, Hôpital Lariboisière, Paris, France.

††Clinique Rhumatologique, Hôpital Saint-Eloi, Montpellier, France.

$\ddagger \ddagger$ Unité de Recherche INSERM no. 18 et Clinique Rhumatologique, Centre Viggo-Petersen, Hôpital Lariboisière, Paris, France.
The interest in these antigens was stimulated by the description of Sharp and his co-workers (1972) of the entity they called 'mixed connective tissue disease', in which the anti-RNP antibodies are the immunological markers the most characteristic of the disease. Since the initial description by Sharp et al., many studies have attempted to define further the clinical significance of antibodies to different soluble nuclear antigens and particularly antibodies to RNP (Koffler et al., 1971; Griffiths et al., 1977). The data obtained have not always been similar. We report here our own studies with 176 sera which contained antibodies to soluble antigens.

\section{Material and methods}

The detection of antinuclear antibodies (ANA) was done by indirect immunofluorescence on $4 \mu \mathrm{m}$ cryostat cut sections of normal young rat liver, using various dilutions of the patient's serum starting at a 1:10 dilution and a commercially obtained polyvalent anti-human immunoglobulins rabbit antiserum labelled with fluorescein isothiocyanate (Institut Pasteur, Paris).

Study of the antibodies to ENA was done on all sera containing ANA which exhibited a speckled pattern of nuclear fluorescence or, at the request of the physician, when mixed connective tissue disease was suspected. This was done using 
precipitation in Agar gel by the technique of Ouchterlony. The preparation of the thymic cells extract and its treatment by RNase or trypsin have been previously described (Peltier et al., 1977a). Each serum was tested against native ENA, ENA treated with RNase, and ENA treated with trypsin. The reactions were read after 3 or 4 days incubation of the plates at $4^{\circ} \mathrm{C}$ in a humid chamber. The sera reacting with the 3 forms of the extract were considered to contain anti-Sm, those reacting only with native ENA to contain anti-RNP, and those reacting with native and RNase-treated ENA (but not with trypsin-treated ENA), to contain antibodies to the soluble nuclear protein antigen. Antibodies to this latter antigen will be described here as 'anti-protein'. The exact specificity of the precipitin lines observed was initially controlled by demonstrating their identity by comparison with precipitin lines of anti-Sm and anti-RNP sera (supplied by E. Tan). Some sera gave more than one precipitin line and were therefore considered as containing multiple antibodies to ENA. An association of anti-Sm and anti-RNP antibodies was most commonly found.

Detection of anti-DNA antibodies was performed using either an indirect immunofluorescent spot test on DNA spread on slides (Osnos et al., 1977), by the radio-immunoassay technique of Farr (Peltier et al., 1974), or by both techniques.

\section{Results}

\section{GENERAL RESULTS}

The sera of 1169 patients were studied. One hundred and seventy-six of these sera gave a positive reaction to ENA on one or more occasions. The majority of the positive sera $(64 \%)$ contained an anti-RNP antibody and a small proportion had either antiSm, anti-protein, or multiple antibodies (Table 1). We had access to the charts of 134 of these 176 patients. Only the clinical data of these 134 patients were used in this study.

The pattern of nuclear fluorescence was available in 166 of the 176 sera with anti-ENA (Table 2). The fluorescence was most frequently speckled $(78 \%)$, less often homogeneous or peripheral. The

Table 1 Detection of anti-ENA: overall results

\begin{tabular}{lcc}
\hline Antibody & $\begin{array}{l}\text { Positive } \\
\text { patients }\end{array}$ & $\begin{array}{l}\text { Patients included } \\
\text { in the study }\end{array}$ \\
\hline Anti-RNP & $113(64 \%)$ & 85 \\
Anti-Sm & $19(11 \%)$ & 18 \\
Anti-protein & $27(15 \%)$ & 20 \\
Multiple antibodies & $17(10 \%)$ & 11 \\
Total & $176(100 \%)$ & 134 \\
\hline
\end{tabular}

speckled pattern was much more common for sera containing anti-RNP $(88 \%)$ than for sera containing anti-Sm (63\%) or anti-protein $(63 \%)$.

As the technique of double precipitation in agarose does not allow even a semi-quantitative $\overrightarrow{\vec{s}^{2}}$ estimation of the concentrations of the differen $\vec{b}$ anti-ENA antibodies in the sera, we have relied fot this estimation on the serum antibody titres obtained at the immunofluorescence ANA reaction, assuming that there would be a direct and relatively closê relationship between the latter and the anti-ENA ${ }^{\infty}$ antibodies titres. As shown in Fig. 1, the distribution $\vec{P}$ of the titres of ANA is apparently different for the sera containing anti-Sm or anti-protein antibodies than for the anti-RNP containing sera. The latten have a serum ANA concentration a little more elevated than the former.

\section{SEROLOGICAL AND CLINICAL} CORRELATIONS

The major clinical manifestations of the patients with anti-ENA are shown in Table 3. The female predominance, the age of onset of symptoms, and the duration of disease since the first symptom are similar for all categories of patients.

The clinical manifestations found most frequentlve among all the groups were arthritis (85 to $100 \%$ po and Raynaud's phenomenon (50 to $76 \%$ ). Fe was present in all groups $(40$ to $73 \%)$. Swoten fingers were common in patients with anti-RNP $(34 \%)$. Other manifestations were observed ing less than one third of the patients. Sjögren's dis. ease was common in patients having anti-soluble nuclear protein $(30 \%)$.

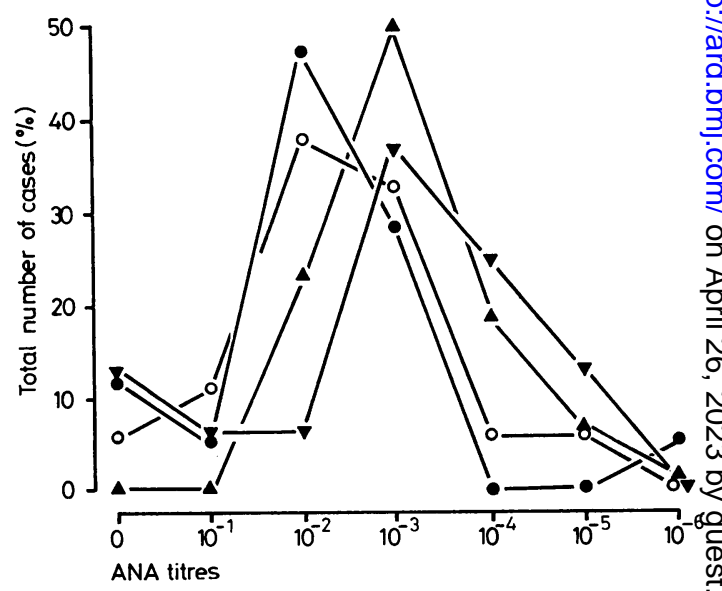

Fig. 1 Distribution of $A N A$ titres in sera with different types of anti-ENA antibodies. - - : anti-protein; o- $0:$ anti-Sm; $\Delta-\Delta$ : anti-RNP; $\nabla-\nabla$ : multiple antibodies. 
Table 2 Fluorescence pattern given by ANA of 172 sera with anti-ENA

\begin{tabular}{lccccc}
\hline Antibody & Number of sera & \multicolumn{2}{c}{ Nuclear fuorescence } & Peripheral \\
\cline { 2 - 5 } & & Speckled & Homogeneous & Mixed \\
\hline Anti-RNP & 115 & $102(88 \%)$ & $5(4 \%)$ & 0 & $8(7 \%)$ \\
Anti-protein & 17 & $12(63 \%)$ & $4(21 \%)$ & $1(5 \%)$ & 0 \\
Anti-Sm & 18 & $12(63 \%)$ & $6(32 \%)$ & 0 & 0 \\
Multiple antibodies & 16 & $9(50 \%)$ & $5(28 \%)$ & 0 & $1(0.5 \%)$ \\
Total & 166 & $135(78 \%)$ & $20(12 \%)$ & $10(6 \%)$ \\
\hline
\end{tabular}

*Homogeneous or peripheral fluorescence at low dilution and speckled at high dilution.

Table 3 Clinical manifestations

\begin{tabular}{|c|c|c|c|c|c|}
\hline & \multicolumn{4}{|l|}{ Antibodies } & \multirow[t]{2}{*}{ Total $(n=134)$} \\
\hline & Anti-RNP $(n=85)$ & Anti-protein $(n=20)$ & Anti-Sm $(n=18)$ & Multiple $(n=11)$ & \\
\hline \multirow{2}{*}{$\begin{array}{l}\text { Sex }(F / M) \\
\text { Age of onset } \\
\text { Mean } \\
\text { Range } \\
\text { Evolution }\end{array}$} & $74 / 11$ & $14 / 6$ & $16 / 2$ & $11 \mathrm{~F}$ & $115 / 19$ \\
\hline & $\begin{array}{l}31 \text { years } 7 \text { months } \\
10-72 \text { years }\end{array}$ & $\begin{array}{l}41 \text { years } 4 \text { months } \\
16-72 \text { years }\end{array}$ & $\begin{array}{l}31 \text { years } 8 \text { months } \\
12-71 \text { years }\end{array}$ & $\begin{array}{l}26 \text { years } 5 \text { months } \\
12-42 \text { years }\end{array}$ & $\begin{array}{l}32 \text { years } 7 \text { months } \\
10-72 \text { years }\end{array}$ \\
\hline $\begin{array}{l}\text { Evolution } \\
\text { Mean }\end{array}$ & 7 years 11 months & 8 years 11 months & 6 years 10 months & 7 years 6 months & 7 years 11 months \\
\hline Range & 3 months-50 years & 8 months-24 years & 6 months-24 years & 4 months-21 years & 4 months -50 years \\
\hline Articular involvement & $79(93 \%)$ & $17(85 \%)$ & $16(88 \%)$ & $11(100 \%)$ & $123(92 \%)$ \\
\hline Raynaud's phenomenon & $65(76 \%)$ & $10(50 \%)$ & $10(55 \%)$ & $8(73 \%)$ & $93(69 \%)$ \\
\hline $\begin{array}{l}\text { Swollen fingers } \\
\text { Muscular involvement }\end{array}$ & $29(34 \%)$ & $1(5 \%)$ & $3(17 \%)$ & $2(18 \%)$ & $35(26 \%)$ \\
\hline $\begin{array}{l}\text { Muscular involvement } \\
\text { Cutaneous sclerosis }\end{array}$ & $\begin{array}{l}15(18 \%) \\
18(21 \%)\end{array}$ & $\begin{array}{l}1(5 \%) \\
4(20 \%)\end{array}$ & $\begin{array}{l}4(22 \%) \\
3(17 \%)\end{array}$ & $\begin{array}{l}0(0 \%) \\
4(36 \%)\end{array}$ & $\begin{array}{l}20(15 \%) \\
29(22 \%)\end{array}$ \\
\hline Fever & $40(47 \%$ & $8(40 \%)$ & $12(66 \%)$ & $\begin{array}{l}4(36 \%) \\
8(73 \%)\end{array}$ & $\begin{array}{l}29(22 \%) \\
68(51 \%)\end{array}$ \\
\hline Serositis & $16(19 \%)$ & $3(15 \%)$ & $3(17 \%)$ & $3(27 \%)$ & $25(19 \%)$ \\
\hline Alopecia & $16(19 \%)$ & $4(20 \%)$ & $5(28 \%)$ & $6(55 \%)$ & $26(19 \%)$ \\
\hline Butterfly rash & $19(23 \%)$ & $6(30 \%)$ & $2(11 \%)$ & $3(27 \%)$ & $30(22 \%)$ \\
\hline Photosensitive rash & $17(20 \%)$ & $5(25 \%)$ & $3(17 \%)$ & $3(27 \%)$ & $28(21 \%)$ \\
\hline $\begin{array}{l}\text { Other rashes* } \\
\text { Neurological involvement }\end{array}$ & $\begin{array}{l}5(6 \%) \\
4(5 \%)\end{array}$ & $\begin{array}{l}3(20 \%) \\
2(10 \%)\end{array}$ & $\begin{array}{l}2(11 \%) \\
1(6 \%)\end{array}$ & $\begin{array}{l}2(18 \%) \\
3(27 \%)\end{array}$ & $12(9 \%)$ \\
\hline Sjögren's disease & $15(18 \%)$ & $6(30 \%)$ & $2(11 \%)$ & $1(9 \%$ & $24(18 \%)$ \\
\hline Definite renal disease & $9(11 \%)$ & $3(15 \%)$ & $5(28 \%)$ & $4(36 \%)$ & $21(16 \%)$ \\
\hline Possible renal disease & $12(14 \%)$ & $5(25 \%)$ & $2(11 \%)$ & $3(27 \%)$ & $22(16 \%)$ \\
\hline
\end{tabular}

*Discoid lupus, bullous rash, or urticaria.

The arthritis was generally benign although 16 patients (10 with anti-RNP) had erosive arthritis and 16 (7 with anti-RNP) had deformities. Seven patients ( 3 with anti-RNP) had rheumatoid nodules.

It must be noted that Raynaud's phenomenon was often the first sign of the disease existing on its own for many years. In certain patients the swollen fingers evolved into definite sclerodactyly.

Abnormalities of the muscles were considered to be present only in patients having, in addition to the clinical symptoms of myalgia (28 of 134 patients) and muscle weakness or atrophy, one or more biological signs suggestive of myositis (elevation of muscles enzymes, abnormal electromyogram, muscle biopsy showing myositis). None of the 20 patients who fitted this category had the heliotrope rash characteristic of dermatomyositis.

Neuropsychiatric manifestations were very heterogeneous. Of the patients with anti-RNP, 2 had seizures disorders of long duration before the onset of their illness, 1 had a history of a facial palsy, and 1 had a serious meningitis during the course of connective tissue disease. Of the patients with anti-Sm 1 had had myasthenia 20 years before the diagnosis of SLE. One of the patients with anti-protein developed a Brown-Sequard syndrome and another had major psychiatric problems. Of the 3 patients with multiple antibodies 2 had psychosis and 1 a pyramidal syndrome.

\section{RENAL MANIFESTATIONS}

A 24-hour urine protein test was done in 106 of the 134 patients with anti-ENA, serum creatinine tests were performed in 110, and 38 patients had a renal biopsy.

Definite renal disease was considered to be present if 24-hour urine was more than $1 \mathrm{~g}(5.95 \mathrm{mmol})$, serum creatinine more than $1.5 \mathrm{mg} / 100 \mathrm{ml}$ (13.26 $\mu \mathrm{mol} / \mathrm{l})$, or if a renal biopsy showed histological abnormalities typical of glomerulonephritis.

Possible renal disease was considered to be present if there was a proteinuria between $250 \mathrm{mg}$ and $1 \mathrm{~g} / 24$ hour and/or minimal glomerular alterations. 
Using these criteria (see Table 3), definite renal disease was found more frequently in patients with anti-Sm or multiple antibodies than in patients with anti-RNP or anti-protein, while possible renal disease was found more frequently in patients with anti-protein or multiple antibodies than in patients with anti-Sm or anti-RNP. Taking the 2 subgroups together seems to show that renal disease is more frequent in patients with anti-protein $(40 \%)$, anti-Sm $(39 \%)$ or multiple antibodies $(63 \%)$, than in those with anti-RNP (25\%).

Table 4 shows the incidence of anti-DNA in 37 patients with anti-ENA who had renal biopsies. It is of interest that a majority (13 out of 15 ) of the patients with histologically significant renal disease (extramembranous, diffuse proliferative, or local proliferative glomerulonephritis) had anti-DNA in addition to anti-ENA. A similar proportion (6 out of 7) is found in the group of patients with antiRNP.

Two patients had renal disease without anti-DNA. The first, with anti-RNP who had extramembranous glomerulonephritis developed nephrotic syndrome after receiving penicillamine; the second, with anti-Sm, had local proliferative glomerulonephritis.

\section{LABORATORY DATA}

As we are dealing with a retrospective study, the laboratory data could not be collected uniformly for all the 134 patients. Therefore, the results in Table $5^{3}$ are expressed as the ratios of the number of positive cases to the number of cases tested. The percentages. given should be considered as indicative of thes? general trend. Anti-DNA, LE cells, and hypo-o complementaemia seem more common in patientso with anti-Sm antibodies than in those with anti RNP or anti-protein, while rheumatoid factors and cryoglobulinaemia seem more common in those with anti-protein.

Pulmonary diffusion capacity was measured in $38 \vec{\circ}$ patients with anti-RNP antibodies and found to be decreased in 21 . Similarly, oesophageal mobility was్ assessed in 44 patients with anti-RNP antibodies andw found to be decreased in 8 . The same data were available in only a small number of patients with anti-Sm, anti-protein, or multiple antibodies.

\section{DIAGNOSIS}

The final diagnoses established in the 134 patients $\vec{P}$ are shown in Table 6.

The largest group (group 1-59 of 134 patients or $44 \%$ ) was that of the patients for whom it was. possible to make the diagnosis of one specific con nective tissue disease (SLE, PSS, rheumatoid arthrig and polymyositis) or of isolated Sjögren's diseä

Table 4 Results of the renal biopsy in 37 pati ents with anti-ENA according to the presence or absence of anti-DNA antibodies

\begin{tabular}{|c|c|c|c|c|c|c|c|c|}
\hline \multirow[t]{2}{*}{ Renal biopsy } & \multicolumn{6}{|c|}{ Antibody to } & \multirow{2}{*}{$\begin{array}{l}\text { Multiple } \\
\text { antibodies }\end{array}$} & \multirow{2}{*}{$\begin{array}{l}\text { Multiple } \\
\text { antibodies an } \\
\text { anti-DNA }\end{array}$} \\
\hline & $R N P$ & $\begin{array}{l}R N P \\
\text { and } \\
D N A\end{array}$ & Protein & $\begin{array}{l}\text { Protein } \\
\text { and } \\
D N A\end{array}$ & $S m$ & $\begin{array}{l}\text { Sm } \\
\text { and } \\
D N A\end{array}$ & & \\
\hline $\begin{array}{l}\text { Normal }(n=9) \\
\text { Minimal glomerular }(n=13) \\
\text { Extra membranous }(n=5) \\
\text { Diffuse proliferative }(n=4) \\
\text { Focal proliferative }(n=6)\end{array}$ & $\begin{array}{l}3 \\
4 \\
1 \\
0 \\
0\end{array}$ & $\begin{array}{l}3 \\
2 \\
2 \\
1 \\
3\end{array}$ & $\begin{array}{l}2 \\
1 \\
0 \\
0 \\
0\end{array}$ & $\begin{array}{l}1 \\
2 \\
1 \\
1 \\
0\end{array}$ & $\begin{array}{l}0 \\
0 \\
0 \\
0 \\
1\end{array}$ & $\begin{array}{l}0 \\
2 \\
0 \\
2 \\
0\end{array}$ & $\begin{array}{l}\mathbf{0} \\
\mathbf{0} \\
\mathbf{0} \\
\mathbf{0} \\
\mathbf{0}\end{array}$ & $\begin{array}{l}0 \\
2 \\
1 \\
0 \\
2\end{array}$ \\
\hline Total number of biopsies $(n=37)$ & \multicolumn{2}{|c|}{19} & \multicolumn{2}{|l|}{8} & \multicolumn{2}{|c|}{5} & 5 & \\
\hline
\end{tabular}

Table 5 Laboratory findings in patients with anti-ENA

\begin{tabular}{|c|c|c|c|c|}
\hline & \multicolumn{4}{|l|}{ Antibody } \\
\hline & Anti-RNP & Anti-protein & Anti-Sm & $\begin{array}{l}\text { Multiple } \\
\text { antibodies }\end{array}$ \\
\hline $\begin{array}{l}\text { Hypergammaglobulinaemia greater than } 1.8 \mathrm{~g} / 100 \mathrm{ml} \\
\text { Anti-DNA } \\
\text { LE cells } \\
\text { Hypocomplementaemia } \\
\text { Leucopenia less than } 4000 \mathrm{WBC} / \mathrm{mm}^{3} \\
\text { Positive rheumatoid factor } \\
\text { Cryoglobulinaemia } \\
\text { Decreased pumonary diffusing capacity } \\
\text { Decreased oesophageal motility }\end{array}$ & $\begin{array}{rr}54 / 75 *(72 \%) \\
24 / 65 & (38 \%) \\
15 / 72 & (20 \%) \\
6 / 68 & (9 \%) \\
27 / 82 & (32 \%) \\
36 / 78 & (46 \%) \\
11 / 55 & (20 \%) \\
21 / 38 & (55 \%) \\
8 / 44 & (19 \%)\end{array}$ & $\begin{array}{l}14 / 19(74 \%) \\
6 / 14(43 \%) \\
6 / 18(33 \%) \\
3 / 15(20 \%) \\
11 / 20(55 \%) \\
10 / 19(53 \%) \\
6 / 13(46 \%) \\
6 / 7(85 \%) \\
3 / 6(50 \%)\end{array}$ & $\begin{array}{l}11 / 13(85 \%) \\
8 / 14(57 \%) \\
7 / 14(50 \%) \\
6 / 12(50 \%) \\
7 / 17(41 \%) \\
6 / 17(35 \%) \\
4 / 13(30 \%) \\
2 / 3(66 \%) \\
2 / 4(50 \%)\end{array}$ & $\begin{array}{l}10 / 11(91 \% \\
6 / 10(60 \% \\
5 / 10(50 \% \\
5 / 11(45 \% \\
6 / 9(67 \% \\
6 / 9(67 \% \\
2 / 9(22 \% \\
1 / 2(50 \% \\
1 / 3(33 \%\end{array}$ \\
\hline
\end{tabular}


For SLE and classical or definite rheumatoid arthritis, the diagnosis was based on the criteria of the American Rheumatism Association.

Group 2 consisted of 34 patients $(25 \%)$ who had an overlap syndrome that is, it was possible to find in each of them clinical and laboratory signs allowing a diagnosis of 2 or sometimes 3 connective tissue diseases. The list of observed syndromes is shown in Table 7. The most frequent syndromes were those associating SLE, scleroderma, or polymyositis.

Group 3 consisted of 31 patients $(23 \%)$ who had a limited clinical syndrome made up of arthritis, Raynaud's phenomenon, and frequently swollen fingers and hypergammaglobulinaemia. Most of those patients were female (26/31). The mean age at the onset of the syndrome was 31 years and 8 months with a range of 16 to 58 years. The mean duration of the syndrome was 5 years and 8 months ranging from 1 to 20 years. Only a small number of these patients presented a manifestation which could be considered as systemic at any one time: transient pericarditis in 4 cases, photosensitisation in 3, leucopenia below 4000 white blood cells $/ \mathrm{mm}^{3}$ $\left(4 \times 10^{9} / 1\right)$, in 3 , and purely clinical muscle manifestations in 1 case.

Group 4 consisted of 10 other patients ( $8 \%$ ) who did not fit into any of the other 3 groups. A detailed list of their diagnoses is given in Table 6 .

Taken together these results do not demonstrate a specificity of the different anti-ENA antibodies for any disease. Two points, however, deserve consideration. (1) SLE, whether existing alone or in association with manifestations of another connective tissue disease (overlap syndromes), is more common in patients with anti-protein (12 out of 20 patients, $60 \%$ ), anti-Sm $(11 / 18,61 \%)$, and multiple antibodies $(9 / 18,43 \%)$ than in patients with anti-RNP $(37 / 85,43 \%)$. (2) Of the 34 patients with overlapping

Table 6 Diagnosis in 134 patients with anti-ENA

\begin{tabular}{|c|c|c|c|c|c|}
\hline \multirow[t]{2}{*}{ Diagnosis } & \multicolumn{4}{|l|}{ Antibody } & \multirow[t]{2}{*}{ Total } \\
\hline & Anti-RNP & Anti-protein & Anti-Sm & Multiple & \\
\hline $\begin{array}{l}\text { Group } 1 \\
\text { Systemic lupus erythematosus } \\
\text { Progressive systemic sclerosis } \\
\text { Polymyositis } \\
\text { Rheumatoid arthritis } \\
\text { Sjögren's disease }\end{array}$ & $\begin{array}{r}19(22 \%) \\
3(4 \%) \\
2(2 \%) \\
7(8 \%) \\
3(4 \%)\end{array}$ & $\begin{array}{l}9(45 \%) \\
0 \\
1(5 \%) \\
2(10 \%) \\
0\end{array}$ & $\begin{array}{l}7(39 \%) \\
0 \\
0 \\
0 \\
0\end{array}$ & $\begin{array}{l}5(46 \%) \\
1(9 \%) \\
0 \\
0 \\
0\end{array}$ & $\begin{array}{r}40(30 \%) \\
4(3 \%) \\
3(2 \%) \\
9(7 \%) \\
3(2 \%)\end{array}$ \\
\hline $\begin{array}{l}\text { Group } 2 \\
\text { Overlap syndromes }\end{array}$ & $22(26 \%)$ & $4(20 \%)$ & $5(28 \%)$ & $3(27 \%)$ & $34(25 \%)$ \\
\hline $\begin{array}{l}\text { Group } 3 \\
\text { Raynaud's phenomenon and polyarthritis }\end{array}$ & $24(28 \%)$ & $1(5 \%)$ & $5(28 \%)$ & $1(9 \%)$ & $31(23 \%)$ \\
\hline $\begin{array}{l}\text { Group } 4 \\
\text { Raynaud's syndrome } \\
\text { Fortuitous laboratory finding } \\
\text { Polyclonal hypergammaglobulinaemia } \\
\text { Polyarthritis and psoriasis } \\
\text { Arthritis and leucopenia } \\
\text { Pericarditis and Raynaud's phenomenon } \\
\text { Arthritis and pericarditis } \\
\text { Leucopenia, arthritis, and pleuritis } \\
\text { Sarcoidosis }\end{array}$ & $\begin{array}{l}1(1 \cdot 2 \%) \\
0 \\
0 \\
0 \\
1(1 \cdot 2 \%) \\
1(1 \cdot 2 \%) \\
1(1 \cdot 2 \%) \\
1(1 \cdot 2 \%) \\
0\end{array}$ & $\begin{array}{l}0 \\
0 \\
1(5 \%) \\
1(5 \%) \\
0 \\
0 \\
0 \\
0 \\
1(5 \%)\end{array}$ & $\begin{array}{l}0 \\
1 \\
0 \\
0 \\
0 \\
0 \\
0 \\
0 \\
0\end{array}$ & $\begin{array}{l}0 \\
1 \\
0 \\
0 \\
0 \\
0 \\
0 \\
0 \\
0\end{array}$ & $\begin{array}{l}1(0.8 \%) \\
2(1.6 \%) \\
1(0.8 \%) \\
1(0.8 \%) \\
1(0.8 \%) \\
1(0.8 \%) \\
1(0.8 \%) \\
1(0.8 \%) \\
1(0.8 \%)\end{array}$ \\
\hline Total & 85 & 20 & 18 & 11 & 134 \\
\hline
\end{tabular}

Table 7 Overlap syndromes

\begin{tabular}{|c|c|c|c|c|}
\hline \multirow{2}{*}{ Diagnosis } & \multicolumn{4}{|l|}{ Antibody } \\
\hline & Anti-RNP & Anti-protein & Anti-Sm & Multiple \\
\hline $\begin{array}{l}\text { SLE-PSS } \\
\text { SLE-polymyositis } \\
\text { SLE-PSS-polymyositis } \\
\text { SLE-RA } \\
\text { PSS-polymyositis } \\
\text { RA-PSS } \\
\text { RA-SLE-PSS }\end{array}$ & $\begin{array}{l}7 \\
8 \\
1 \\
1 \\
1 \\
3 \\
1\end{array}$ & $\begin{array}{l}2 \\
0 \\
0 \\
0 \\
0 \\
1 \\
1\end{array}$ & $\begin{array}{l}1 \\
2 \\
1 \\
0 \\
1 \\
\mathbf{0} \\
\mathbf{0}\end{array}$ & $\begin{array}{l}1 \\
0 \\
0 \\
1 \\
0 \\
0 \\
1\end{array}$ \\
\hline Total & 22 & 4 & 5 & 3 \\
\hline
\end{tabular}


features of two or more connective tissue diseases, the majority ( 22 out of 34 patients, $65 \%$ ) has antiRNP antibodies while only a small number had anti-protein $(4 / 34,12 \%)$, anti-Sm $(5 / 34,15 \%)$, or multiple antibodies $(3 / 34,9 \%)$. The same holds true for the patients with the limited clinical syndrome combining mainly polyarthritis and Raynaud's phenomenon.

This suggests that presence of anti-RNP in a patient can favour the diagnosis of an overlap syndrome or of the mild connective tissue disease seen in patients of group 3. Other antibodies are rather suggestive of the diagnosis of SLE.

\section{Discussion}

Technical problems will be discussed here only briefly. The immunodiffusion technique is less sensitive than passive haemagglutination. For instance, Sharp et al. (1976) using both techniques comparatively, found discrepancies in favour of haemagglutination in 2 of 67 sera with anti-RNP and in 6 of 27 sera having antibodies specific for an RNase resistant antigen.

In this study, the majority of sera with anti-RNP gave a speckled pattern of nuclear fluorescence. The percentages observed are lower for sera with anti-Sm, anti-protein, and multiple antibodies. This difference can probably be explained by the more frequent presence in these sera of anti-DNA, antiDNA protein, and other antibodies (Tan, 1967).

The finding, in sera with anti-RNP, of titres of ANA higher than in sera with anti-Sm, has already been observed (Sharp et al., 1976).

Most important in fact, is the discussion of the clinical significance of anti-RNP antibodies. Two major questions arise here: is the presence of antiRNP in the serum of patient, characteristic of the entity described by Sharp et al. (1972) as 'mixed connective tissue disease', and, are anti-RNP antibodies present in a patient having a well defined connective tissue disease associated with particular features or a better prognosis?

Seventy-four per cent of Sharp's patients with anti-RNP have what he called a 'mixed connective tissue disease'. This disorder is characterised by overlapping features of SLE, PSS, and polymyositis especially a non-deforming polyarthritis, Raynaud's phenomenon, swollen fingers, myositis, and pulmonary as well as oesophageal involvement. These patients were reported to have a low incidence of nephritis and a good general prognosis. The other patients in Sharp's series with anti-RNP, had SLE $(12 \%)$, PSS $(8 \%)$, and an undifferentiated mild connective tissue disease $(6 \%)$.

Our results are somewhat different since, of 85 patients with anti-RNP antibodies, $40 \%$ have well defined connective tissue disease (SLE, PSS polymyositis, or RA), $26 \%$ have overlap syndrome?. similar to those already described in the literature (Tuffanelli and Winkelmann, 1961; Dubois et al $\overrightarrow{\text { क्? }}$ 1971), and $28 \%$ a limited clinical syndrome con sisting of Raynaud's phenomenon and a more of less isolated polyarthritis.

In fact, our results are in agreement with previousl $\frac{{ }^{\circ}}{{ }^{\prime}}$ published series where no diagnostic specificity was found for anti-RNP antibody (Mattioli and Reichlin's 1971 ; Parker, 1973; Notman et al., 1975).

Two explanations have been proposed for the good prognosis and the low incidence of nephritis ifg patients with anti-RNP antibodies. Mattioli and Reichlin (1971) found a very low incidence of antip DNA antibodies in their patients with anti-RNE antibodies. One experimental study showed a prop tective effect of ENA on the development of nephrit in NZB/NZW mice (Morris et al., 1975).

We should mention here that two patients with anti-RNP and anti-DNA antibodies died durin $\vec{g}$ the course of our study. They were both cases of SLE. The first died of renal failure and the second of acute respiratory failure.

Our results indicate a narrower specificity $\overrightarrow{\alpha \vec{b}}$ anti-Sm and anti-protein for SLE, since this degos nosis was made in more than half the patients witb these antibodies. These figures never reach 9 the specificity claimed by Tan and Kunkel (1966) ' fo anti-Sm antibodies.

Finally, it must be concluded that the antibodie to ENA, in particular anti-RNP and anti-Sm although they are of great interest in our knowledge of this group of diseases, are far from reaching, for the physician, the diagnostic and prognostic value of other antibodies mainly anti-DNA.

The authors acknowledge here T. Haim for her excellent technical assistance and Dr N. Rothfield. for reading the manuscript and for its translationg They also thank the following who made the charts of their patients available: Dr Bétail (Clermongs Ferrand), Drs Cayla, Debray, Godeau, Homberg, Mery, and Seligman (Paris), Dr Massias (Clamart Drs Touraine and Villiaumey (Créteil).

\section{References} soluble acid protein of the cell nucleus which reacts with serum from patients with systemic lupus erythematosus an Sjogren's syndrome. Journal of Clinical Investigation, $5 \Phi_{3}$ 264-272.

Alspaugh, M. A., and Tan, E. M. (1973). Antibodies tor cellular antigens in Sjögren's syndrome. Journal of Clinic Investigation, 55, 1067-1073. 
Appelboom, T., Kahn, M. F., Peltier, A. P., and De Seze, S. (1974a). Rhumatisme dysimmunitaire du syndrome de Raynaud: Rhumatisme inflammatoire, Syndrome de Raynaud, Facteurs antinucléaires mouchetés et anticorps antiribonucléoprotéine: une nouvelle entité? Annals of Internal Medicine, 125, 841-848.

Appelboom, T., Kahn, M. F., Peltier, A. P., and De Seze, S. (1974b). Syndrome de Raynaud avec arthrite, facteurs antinucléaires mouchetés, anticorps anti-ECT: une nouvelle entité. In L'Actualite Rhumatologique, p. 30. Ed. by S. de Seze et al. L'Expansion Scientifique, Paris.

Barland, P., Hamburger, M., and Hodes, S. (1975). The clinical significance of anti-Sm and anti-RNP antibodies. Arthritis and Rheumatism (New York), 18, 384.

Criteria for diagnosis and classification of rheumatic diseases. (1973). In Primer of the Rheumatic Diseases. Journal of the American Association, 224, 799-803.

Dorsch, C. A., Feinglass, E. J., and Stevens, M. B. (1977). Clinical significance of antibodies to extractable nuclear antigen (ENA) in systemic lupus erythematosis (SLE). Arthritis and Rheumatism, $20,114$.

Dubois, E., Chandor, S., Friou, G. J., and Bischel, M. (1971). Progressive systemic sclerosis (PSS) and localized scleroderma (morphea) with positive LE cell test and unusual systemic manifestations compatible with systemic lupus erythematosus SLE. Medicine, 50, 199.

Farber, S. J., and Bóle, G. G. (1976). Antibodies to components of extractable nuclear antigens (ENA). Archives of Internal Medicine, 136, 425-431.

Griffiths, I. D., Mumford, P., Maini, R. N., and Scott, J. T. (1977). Clinical significance of antibodies to extractable nuclear antigens (ENA). Annals of the Rheumatic Diseases, 36, 479 (Abstract).

Holman, H. R., Deicher, H. R., and Kunkel, H. G. (1959). The LE cell and the LE serum factors. Bulletin of the New York Academy of Medicine, 35, 409-418.

Koffler, D., Carr, R., Agnello, V., Thorburn, R., and Kunkel, H. G. (1971). Antibodies to polynucleotides in human sera: antigenic specificity and relation to disease. Journal of Experimental Medicine, 134, 294-312.

Leibfarth, J. H., and Perselin, R. H. (1976). Characteristics of patients with serum antibodies to extractable nuclear antigens. Arthritis and Rheumatism, 19, 851-856.

Mattioli, M., and Reichlin, M. (1971). Characterization of a soluble nuclear ribonucleoprotein antigen reactive with SLE sera. Journal of Immunology, 107, 1281-1290.

Morris, A. D., Littleton, C., Corman, L. C., Esterly, J., and Sharp, G. C. (1975). Extractable nuclear antigen effect on the DNA anti-DNA reaction and NZB/NZW mouse nephretis. Journal of Clinical Investigation, 65, 903-907.

Northway, J. D., and Tan, E. M. (1972). Differentiation of antinuclear antibodies giving speckled staining patterns in immunofluorescence. Clinical Immunology and Immunopathology, 1, 140-154.

Notman, D. D., Kurata, N., and Tan, E. M. (1975). Profiles of antinuclear antibodies in systemic rheumatic diseases. Annals of Internal Medicine, 83, 464-469.
Osnos, M. C., Cyna, L., Haim, T., Peltier, A. P., Kahn, M. F., and Ryckewaert, A. (1977). Anticorps anti-acide désoxyribonucléique: comparaison fournie par trois méthodes de recherche. Revue du Rhumatisme, 44, 73-78.

Parker, M. D. (1973). Ribonucleoprotein antibodies frequency and clinical significance in systemic lupus erythematosus, scleroderma and mixed connective tissue disease. Journal of Laboratory and Clinical Medicine, 82, 769-775.

Peltier, A. P., Aussel, C., Haim, T., and Cyna, L. (1977a). Ribonucleoprotein (RNP) soluble nuclear antigen: demonstration of its reaction with serum antibodies by counter-immunoelectrophoresis and further partial characterization. Journal of Immunological Methods, 16, 153-163.

Peltier, A. P., Haim, T., and Kahn, M. F. (1977b). A new soluble nuclear antigen. XIVth International Congress of Rheumatology, San Francisco, 26 June-1 July 1977, Abstract no. 81.

Peltier, A. P., Hugues, G. R. V., Kahn, M. F., and Haim, T. (1974). Détection des anticorps anti-acide désoxyribonucléique du sérum par la méthode radio-immunologique de Farr. Nouvelle Presse Medicale, 3, 649-653.

Reichlin, M., and Mattioli, M. (1972). Correlation of a precipitin reaction to an RNA protein antigen and a low prevalence of nephritis in patients with systemic lupus erythematosus. New England Journal of Medicine, 286, 908-911.

Sharp, G. C. (1975). Mixed connective tissue disease. Bulletin of Rheumatic Diseases, 25, 828-831.

Sharp, G. C. (1975). Mixed connective tissue disease-Overlap syndromes. Clinics in Rheumatic Disease, 1, 561-572.

Sharp, G. C., Irwin, W. S., May, C. M., Holman, H. R., McDuffie, F. C., Hess, E. V., and Schmid, F. R. (1976). Association of antibodies to ribonucleoprotein and Sm antigens with mixed connective tissue disease, systemic lupus erythematosus and other rheumatic diseases. New England Journal of Medicine, 295, 1149-1154.

Sharp, G. C., Irwin, W. S., Tan, E. M., Gould, R. G., and Holman, H. R. (1972). Mixed connective tissue disease. An apparently distinct rheumatic disease syndrome associated with a specific antibody to an extractable nuclear antigen (ENA). American Journal of Medicine, 52, 148-159.

Tan, E. M. (1967). Relationship of nuclear staining patterns with precipitating antibodies in systemic lupus erythematosus. Journal of Laboratory and Clinical Medicine, 70, 800-812.

Tan, E. M., and Kunkel, H. G. (1966). Characteristics of a soluble nuclear antigen precipitating with sera of patients with systemic lupus erythematosus. Journal of Immunology, 96, 464-471.

Tuffanelli, D. L., and Winkelmann, R. K. (1961). Systemic scleroderma. A clinical study of 727 cases. Archives of Dermatology, 84, 359-371.

Wolfe, J. F., Adelstein, E., and Sharp, G. C. (1977). Antinuclear antibody with distinct specificity for polymyositis. Journal of Clinical Investigation, 59, 176-178. 